that the urine from two cases of tuberculosis of the bladder and diabetes respectively had many points in common probably resides in the fact that the subjects of the disease in question are either constitutional "hyperacids" or the subjects of retarded nutrition-Bouchard's "ralentis." In the first case the low specific gravity, the rising chlorides, and the pale colour of the urine indicate amongst other signs that the defences of the organism are breaking down and that the tuberculous affection of the bladder of twelve months' standing is threatening to become generalised. The organism, as Dr. Gilchrist says, is becoming demineralised, the chlorides now following an earlier excessive excretion of phosphates. The supposition that this specimen of urine is taken from the subject of a gouty or atonic scrofulous diathesis, where such a resistance to infection is likely to occur, is rendered probable by the low figure of the phosphates ( 0.84 gramme) given by Mr. Clayton. If here the solid residue is calculated by densimetry, as Dr. Gilchrist did in his paper, the proportion of phosphoric acid stands at 1 in 33 ; precisely the same proportion is also found by taking the average of the three specimens of Mr. Clayton's case of glycosuria. It would be instructive to know the diet prescribed in this case of glycosuria; the relatively high urea and phosphates found in specimen $\mathrm{C}$ lead to the conclusion that meat was a liberal item in the patient's dietetic treatment.

Judging by Dr. S. Vere Pearson's ${ }^{3}$ and Mr. A. W. Pereira's ${ }^{4}$ clinical observations on the apparent uselessness of urea in the treatment of tuberculosis, Dr. Gilchrist's theoretical objections seem to be justified. Concerning the one point on wlich Dr. H. Harper and Dr. Gilchrist agree with most modern opinion-that is, on the necessity for a highly nitrogenous diet in the treatment and prophylaxis of tuberculosis -I should feel inclined to follow the suggestion of Dr. Gau. trelet and to draw the supply of nitrogen at intervals from the leguminous plants; we know in fact that peas and lentils contain more nitrogen than meat in the proportion of about 46 to 42 .

I am, Sirs, yours faithfully,

Nice, Dec. 22nd, 1902.

J. C. B. STATHAM, Captain, R.A.M.C.

\section{SIR THOMAS BROWNE'S EVENING HYMN.}

\section{To the Editors of THE LANCET.}

SiRs, - In The LanceT of Dec. 20th, 1902, p. 1702, the reviewer of a new edition of the "Religio Medici" states that he cannot call to mind any editor who has pointed out the similarity between Bishop Ken's Evening Hymn and the dormitive which Sir Thomas says he took "to bedward." In Gardiner's edition (1845) there is the following note: "Compare this with the beautiful and well-known 'Evening Hymn' of Bishop Ken, and these again with several of the Hymni Ecclesiæ, especially that beginning 'Salvator Mundi, Domine,' with which Ken and Browne, both Wyckhamists, must have been familiar."

I am, Sirs, yours faithfully,

Baltimore, Jan.2nd, 1903.

WM. OSLER.

\section{THE DISCHARGE OF LARVAE FROM THE STOMACH.}

To the Editors of THE LANOET.

SIRS, - The references in THE LANCET of Sept. 27ti (p. 891) and Nov. 29th (p. 1487), 1902, to the vomiting of the larvæ of dipterous insects, remind me that in the summer of 1900 I met with such a case. This was of an infant in arms, fed by the bottle, who was said to have vomited maggots. The mother was directed to preserve the maggots if the vomiting was repeated, and some days afterwards a cluster of about 35 or 40 larvæ was produced. These were alive and being placed in water lived till the next day. They were "club-shaped," tapering regularly from head to tail, and measured from four to eight millimetres in length; one was much longer, being about 11 millimetres. They had distinct red eyes. A number were sent to the Clinical Research Association, which said it was unable to identify them. It was necessary to take the mother's word that they were actually vomited by the infant, but there could be no reasonable doubt about it. They were only noticed twice and were probably not sought for in the motions.
Beyond some slight gastro-intestinal disturbance common in bottle-fed infants in summer, there was little the matter with the child.-I am, Sirs, yours faithfully,

Edgeworthstown.

J. F. KEENAN, M.B. R.U.I.

\section{RIGHT-HANDEDNESS AND LEFT- BRAINEDNESS.}

\section{To the Editors of THE LANCET.}

SIRs, - With all due deference to a master in science like Sir Samuel Wilks I would like to observe that in this, as with many other rather obscure physico-mental acts, we should never lose sight of the three great fundamental modes and methods of reflex cerebral activity-reason, sensation, and will. Sensation inclines us to adopt modes of action most agreeable to the present comfort and pleasure of the individual; reason suggests what ought to be the mode and will, or more properly speaking volition (for I suppose there must be a faculty of this nature), determines what the mode shall be. The determination of a preferential right-handedness is one of these modes due to a cerebro-spinal functronal activity. A subject of this kind, not easily susceptible of scientific demonstration, is very apt to make one drift into a form of physiological transcendentalism, but what I mean to urge is that there is no satisfactory and decided clinical evidence that right handedness has a structural foundation but that all such manifestations depend on outside influences acting on the brain centres - the combined result of education and necessity. Let it be understood, however, that that centre is not preferential but a centre common to both the left and right side of the system. How otherwise explain the philosophy of habit and, indeed, of many of the well-recognised instincts of our nature? That the left hand should by no means hold a subservient position in reference to the right may readily be accepted if we consider the dual functional activity as seen in many handicrafts. In the days of a less exalted civilisation, before steam was so universally accepted as the great motor power, I have watched with interest and admiration the deftness with which the hand-loom weavcr used both hands in his daily occupation. His was an ambidexterity illustrating not only the aristocratic position of the left hand but the fact of left-handedness being not only a possibility - a desideratum-but a necessity of his workaday existence. No one can deny that right-handedness is preferential and, indeed, almost a physical necessity because it appeals to the present, and often urgent, necessities of the individual. Left-handedness is potential and takes the position of a reserve force, a power which can be called into action under conditions of necessity when the other is in abeyance. This is all I claim for it. As Sir Samuel Wilks observes in his criticism, man is a two-sided animal with an inequality as to functional power on one side as compared with the other. No doubt about this, but like many functional processes under the direct dominion of brain man's nature is amenable to outside influences and the conditions, as before remarked, of his environment. He can adapt himself to circumstances and make his left hand serve his needs if the right cannot. Hence education, hence training of children, hence the necessity of what we know as professional teaching-in short, of any kind or description of cult whatever. Apologising for the length and prosiness of this letter I trust that though I may, like Mr. Kipling's orang-outang "Bimi," seem to have "too much ego in my cosmos," you will give me credit for the desire to give an all-important point like this all the careful consideration it deserves.

I am, Sirs, yours faithfully,

Rothwell, Northamptonshire. JAMES MORE, M.D. Edin.

\section{INTRAVASCULAR ANTISEPSIS. To the Editors of THE LANCET.}

SIRS,-Due importance will be attached by clinical observers to the results published in THE LANCET of Jan. 10th, p. 98, of Dr. J. M. Fortescue-Brickdale's able investigations into the subject of intravenous antisepsis, which conclusively demonstrate the inefficacy for direct germicidal purposes of our antiseptics of the day, used in the shape of intravenous injections. Intravenous medication, however, is a distinct and much wider subject to which it may be premature to apply the same sweeping conclusions. Indeed, the proof that the injections are inert as germicides favours 